\title{
A study of incidence of EGFR mutations in non-smoker adenocarcinoma of the lung: disparity between north and south indian patients
}

\author{
Manish Pungliya ${ }^{1 *}$, Minhas Sachin ${ }^{2}$, Nagasamy Soumittra ${ }^{3}$, Patil Shekar ${ }^{4}$ and Aggarwal Shyam² \\ *Correspondence: mpungliya@ayugen.com CrossMark \\ 'AyuGen Biosciences Pvt Ltd, Shivajinagar, Pune 411005, India. \\ ²Department of Medical Oncology, Sir Ganga Ram Hospital, New Delhi 110060, India. \\ ${ }^{3}$ Senior Scientist, SN ONGC Department of Genetics and Molecular Biology, Vision Research Foundation, Sankara Nethralaya, Chennai \\ 600006, India. \\ ${ }^{4}$ Consultant Medical Oncology, HCG Oncology, Bengaluru 560027, India.
}

\begin{abstract}
Background: Lung cancer is the leading cause of cancer deaths worldwide for both men and women. It is the number three cancer among Indian men. Chemotherapy for non-small cell lung carcinoma (NSCLC), which accounts for approximately $85 \%$ of lung cancer cases, remains marginally effective. Anti-EGFR therapies have been developed to intervene in the EGFR signalling cascade in NSCLC. Mutations in EGFR gene are an important factor in achieving the desired outcome in case of such patients. We sought to analyse the presence of mutations in EGFR gene in Asian Indian adenocarcinoma patients to highlight the implications for using such therapies in one of the highest populated state. It may also show importance of using a relevant population for research in drug development involving such therapies.

Method and findings: A retrospective multicentre study was performed where tumour samples of non-smoker or ex-smoker adenocarcinoma patients were analyzed for EGFR gene mutations. We used ARMS-Scorpion's real time PCR method for mutation analyses. Overall, 50 NSCLC patients were included in the mutation analyses. The EGFR mutation positive rate was $56 \%$ ( $\pm 14 \%$ ). South Indians had a higher mutation rate $(68 \% \pm 17 \%)$ than North Indians $(41 \% \pm 21 \%, \mathrm{p}=0.06)$. South Indian female NSCLC patients had a higher mutation rate than that of in North Indian female NSCLC patients. $(\mathrm{p}=0.02)$.

Conclusions: The EGFR mutation rate in Indian NSCLC patients was higher than that of the European or other western populations. Such a high rate of positive mutation in non-smoker lung adenocarcinoma is remarkable \& has important implications in the management of such cases. There is also a disparity in the mutation rate between north \& south India especially in women. It is therefore important to evaluate the EGFR mutation status before prescribing the tyrosine kinase inhibitors in the case of non-smoker lung adenocarcinoma patients from North \& South India to have effective treatment outcome.
\end{abstract}

Keywords: EGFR mutation, lung cancer, genetics of lung cancer, NSCLC

\section{Introduction}

Lung cancer is the leading cause of cancer deaths worldwide for both men and women [1]. It is the number three cancer among Indian men [2]. Chemotherapy for non-small cell lung carcinoma (NSCLC), which accounts for approximately $85 \%$ of lung cancer cases, remains marginally effective [3]. Genomic research has unveiled tumour cell growth pathways that can be targeted with newer anticancer therapies having better efficacy \& safety. One of such signalling growth pathway is human epidermal growth factor receptors (HER \& EGFR members). EGFR is a transmembrane tyrosine kinase receptor that plays a crucial role in regulating cell division and death. EGFR is the cell surface receptor of extracellular protein ligands [4]. Genetic mutations in the EGFR gene may result in cancer [5]. Mutations in the tyrosine kinase domain of the EGFR gene increase the activity of the intracellular signalling cascades. This results in the increased proliferation activity of the tumour cells, finally leading to an inhibition in apoptosis and then metastasis [6-11,12].

Anti-EGFR therapies have been developed to intervene in the EGFR growth cascade [13-15]. EGFR belongs to the HER family of receptors which comprise EGFR(HER1/ErbB1), ERBB2(HER2), ERBB3(HER3) and ERBB4(HER4). The HER receptors are known to be activated by binding to different ligands, including EGF, TGFA, heparin-binding EGF-like growth factor, amphiregulin, betacellulin, and epiregulin. After ligand binding to the extracellular domain of the receptor, the receptor forms functionally active dimmers. Dimerization induces the activation of the tyrosine kinase domain, which leads to autophosphorylation of the receptor on multiple tyrosine residues. This leads to activation of a series of intracellular signaling cascades to affect gene transcription, which in turn 
Pungliya et al. Journal of Cancer Therapeutics \& Research 2014,

results in cancer cell proliferation, reduced apoptosis, invasion and metastasis.

The gene is located on the chromosome $7 \mathrm{p} 12$ \& has many conserved domains. It has about 28 exons consisting of 1211 amino acids. Exons 18 through 21 corresponds to the tyrosine kinase domain which is very critical for the response to antiEGFR therapies. It has been seen that presence of activating or driver mutations in this domain of EGFR gene has been associated with response to the anti-EGFR therapies [16-20]. Mutation incidence in the EGFR gene has been shown to be different in different ethnicities [21-23]. Lung adenocarcinoma patients with Asian descent have higher incidence of EGFR mutations than that of European descent [23]. Presence of mutation was also correlated with smoking status \& gender $[\mathbf{2 4 , 2 5 ]}$. It has been seen that non-smoker NSCLC patients have much higher incidence of mutations in EGFR gene than smokers $[\mathbf{2 4 , 2 5 ]}$. It has been observed that the mutations are profound in non-smoking individuals (about 6.5 times higher) than smokers, 4.4 times higher in adenocarcinoma than other sub class of NSCLC, 1.7 times higher in females than males and $27-60 \%$ East Asians (compared to Europeans 8-13.3\%) $[26,44]$. Therefore, it is important to understand the mutation status before starting the treatment with anti-EGFR therapies.

There have been very few studies involving Indian lung cancer patients response to tyrosine kinase inhibitors $[\mathbf{2 7 , 2 8 ]}$ \& these studies showed some benefit of using TKIs. These studies didn't include the genetic evaluations of the tumour samples before initiation of the anti-EGFR treatment \& therefore those results were based on patient population that has not been selected using genetic evaluations of the tumor samples.

However, a recent survey of EGFR mutations in Asian population (PIONEER study) [44] showed only $22 \%$ of EGFR mutation positive rate in a subgroup of Indian ethnic background patients which is lower than the rate observed by Sahoo et al., [26]. In our study we sought for the presence of EGFR mutations in non-smokers NSCLC patients in Indian population.

\section{Methods \\ Patients}

Tissue blocks of tumor specimen were obtained from 55 nonsmokers and ex-smokers suffering with lung adenocarcinoma from two centres. One centre was in North India (Sir Ganga Ram Hospital, New Delhi) and second centre was in South India (HCG Oncology, Bengaluru). This study was approved by the Institutional Ethics Committee of Sir Gangaram Hospital, New Delhi \& HCG Oncology, Bengaluru. Written informed consent of all participants was taken. This consent was approved by the ethics committees of the respective institutions mentioned above \& it was conducted by these institutions as per the ethical principles for medical research (Declaration of Helsinki). Non smokers were defined as those who had smoked fewer than 100 cigarettes in their lifetime. Ex-smokers were defined as those who had smoked more than 100 cigarettes in their lifetime but had stopped smoking for at least 1 year before recruitment. Light ex-smokers were defined as those who had stopped smoking more than 15 years ago and had smoked fewer than 10 packs per year. Written informed consent for the use of tissues for molecular analysis was taken from patients at the time of procurement of tumor specimens.

\section{DNA extraction and mutation detection}

Lung biopsies/surgical tissue specimens of non-smoker or ex-smoker adenocarcinomas were analyzed for somatic EGFR mutation status. DNA was extracted from the paraffin embedded tissue specimens using QIAamp DNA FFPE tissue kit (Qiagen, $\mathrm{GmBH}$, Germany) according to manufacturer's protocol. The extracted DNA was eluted in 50ul of buffer ATE.

The 29 reported somatic mutations were detected using DxS EGFR mutation detection kit (Qiagen). This method detects presence of 29 known mutations in exons 18 through 21 of EGFR gene. In exon 18 it checks for presence of G719X mutation (detects G719S, G719A or G719C but does not distinguish them). In exon 19 it checks for presence of 19 deletions but does not distinguish between them. In exon 20 it checks for presence of T790M, S768I \& 3 insertions (does not distinguish the insertions). In exon 21 it checks for presence of L858R \& L861Q. The method is based on ARMS PCR technology in which primers for 29 mutations are designed based on Scorpions technology. A $25 \mathrm{ul}$ reaction containing $5 \mathrm{ul}$ of not more than 20ng of DNA was set up for real-time PCR reaction according to the manufacturer's protocol. For quality assessment we sent two EGFR mutation positive samples to the external laboratory for confirming our results \& both of them matched with our findings.

\section{Data analyses}

Samples were called positive or negative qualitatively depending on presence of mutations. The statistical significance was calculated using Chi-square test. The main variables in our analyses are gender \& ethnic background (no smoking status since all are non-smokers). We have done the analyses separately within each variable $\&$ therefore we have not done statistical correction for multiple testing in our analyses.

\section{Results}

In this study, we enrolled 55 cases of non-smoker, advanced, inoperable adenocarcinoma of lung (grade 3 \& higher) after June 2008 in a retrospective fashion. 26 patients were enrolled from Sir Ganga Ram Hospital, New Delhi (North India) and 29 from Healthcare Global Hospital, Bangalore (South India) (Table 1). Mutation analysis was possible in 50 of the 55 samples. The five samples did not have sufficient amplifiable DNA to perform the mutation analyses. There were 28 females \& 22 males. There was no difference in male to female ratio among the samples from North \& South India.

Of the 50 samples $28(56 \% \pm 14 \%)$ were positive for EGFR 
Table 1. Patient Demographic characteristics.

\begin{tabular}{l|lll}
\hline \multirow{2}{*}{ Variables } & \multicolumn{2}{|c|}{ Counts } & Total \\
\cline { 2 - 3 } & North India & South India & \\
\hline Number of patients & 26 & 29 & 55 \\
Male & 11 & 13 & 24 \\
Female & 15 & 16 & 31 \\
Age (mean) in years & 61 & 59 & 60 \\
\hline
\end{tabular}

mutations (Table 2). Of the 28 females 17 (61\%) and of 22 males 11 (50\%) were positive for EGFR mutations. There was no statistically significant difference in mutation rate between males \& females $(p=0.45)$.

Table 2. EGFR mutation status.

\begin{tabular}{|c|c|c|c|}
\hline \multirow[t]{2}{*}{ Variables } & \multicolumn{2}{|c|}{ EGFR mutation } & \multirow[t]{2}{*}{ Total } \\
\hline & Positive & Negative & \\
\hline North India & $9(41 \%)$ & 13 & 22 \\
\hline South India & $19(68 \%)$ & 9 & 28 \\
\hline Male & $11(50 \%)$ & 11 & 22 \\
\hline Female & 17 (61\%) & 11 & 28 \\
\hline
\end{tabular}

Of the 22 samples from North India 9 were positive for mutations $(41 \% \pm 21 \%)$. Of the 28 samples from South India 19 were positive for mutations $(68 \% \pm 17 \%)$. There is a trend of higher mutation positives in South Indians compared to North Indians $(p=0.06)$. Among the females 5 of the $13(38 \% \pm 26 \%)$ North Indian NSCLC samples were mutation positive compared to 12 of the $15(80 \% \pm 20 \%)$ South Indian NSCLC samples. There was a statistically significant difference in the mutation status among north \& south Indian females $(p=0.02)$. No such difference was seen in the male NSCLC samples.

The most common mutations observed in this study were deletions in exon $19(17 / 28,61 \%)$ followed by L858R in exon $21(10 / 28-36 \%)$, G719X in exon $18(2 / 28-7 \%)$ and insertions in exon $20(1 / 28-3.6 \%)$. Two samples (4\%) were found to have two different mutations (L858R in exon 21 and deletion in exon 19). Interestingly both samples were from South India.

\section{Discussion}

Our study in non-smoker Indian lung adenocarcinoma patients showed $56 \%$ EGFR mutation positive rate. This rate is higher than that of the European or other western populations in which it is in the range of 17 to $25 \%$ [29]. Such a high rate of mutation positives in non-smoker lung adenocarcinoma is remarkable \& has important implications in case of newer targeted therapies like tyrosine kinase inhibitors. This mutation rate was similar to previous study in Indian lung cancer patients [26] and consistent with results from the studies involving Asian populations $[25,30,31,44]$.
We chose ARMS PCR technology for detection of mutations because of its higher sensitivity \& specificity than sequencing based methods resulting in high false negative rates $[32,33]$. This method has also been used previously in many studies involving response to TKIs [34-36].

Interestingly, we observed that in our sample south Indians have higher rate of mutation positive than north Indians (68\% vs $41 \%)$. This is surprising considering we were looking at somatic mutations \& not germline mutations or polymorphisms in which case the genetic differentiation may exist due to difference in ancestral background. However, the difference in the incidence of somatic mutation rates in EGFR gene between caucasians \& east-asians is known \& widely reported. This can be one of the explanations for having such difference in our study population considering that there is a genetic differentiation between North (Indo-european speaking) \& South Indians [37] (Dravidian speaking). North Indians are closer to European genetically \& have caucasoid admixture while South Indians are ethnically considered as australoid [38].

Liu et al., [39] previously showed that presence of high frequency of EGFR somatic mutations in Asian patients was also associated with higher incidence of germline polymorphisms in the EGFR gene. It will be interesting to study whether South Indians have higher rates of EGFR germline mutations and polymorphisms than that of North Indians. If so this could also explain why South Indians are tend to have higher somatic mutations in EGFR gene than North Indians.

We also need to confirm the observed higher difference in the mutation rates between North \& South Indians in larger sample size. It will be interesting to see if the difference remains same if we increase the sample size. We also want to point out that trend is driven by primarily by higher mutation rate in female samples from South India compared to that of North India ( $p=0.02)$. The same trend was not seen in male patient samples. However, this needs to be confirmed in larger sample size and also by looking at the presence of germline polymorphisms between males \& females which may also drive the somatic mutation rates. This is because a trend of decrease in lung adenocarcinoma risk was found in female subjects with hormone replacement therapy (HRT) and harbouring a higher number of protective EGFR SNPs (single nucleotide polymorphisms) near the tyrosine kinase domain of EGFR gene [40]. The EGFR SNPs have a cumulative effect on decreasing lung adenocarcinoma risk in never-smoking women with HRT use.

There was another study from India by Sahoo et al., [26] which screened lung cancer samples from all of India. In this study the overall incidence of mutation was around 52\% which is similar to what we have seen in this study (56\%). In the same study it was shown that there was a higher mutation rate in females than males which was not significant in our case probably due to the smaller sample size in our study. They also report differences in mutation rates specifically for mutations in exon 18\&19\& gender which was also not 
Pungliya et al. Journal of Cancer Therapeutics \& Research 2014, http://www.hoajonline.com/journals/pdf/2049-7962-3-4.pdf

Table 3. Details of EGFR mutations in patients.

\begin{tabular}{|c|c|c|c|c|c|c|c|c|c|c|}
\hline \multirow[t]{2}{*}{ Subject Code } & \multirow{2}{*}{$\begin{array}{l}\text { Gender } \\
\text { (F-Female, } \\
\text { M-Male) }\end{array}$} & \multirow{2}{*}{$\begin{array}{l}\text { Age } \\
\text { (in years) }\end{array}$} & \multirow{2}{*}{$\begin{array}{l}\text { South or } \\
\text { North Indian }\end{array}$} & \multicolumn{6}{|c|}{ EGFR Mutation type } & \multirow[t]{2}{*}{ \# of mutations } \\
\hline & & & & $\begin{array}{l}\text { G719X } \\
\text { (exon 18) }\end{array}$ & $\begin{array}{l}\text { Deletions } \\
\text { (exon 19) }\end{array}$ & $\begin{array}{l}\text { S768I } \\
\text { (exon 20) }\end{array}$ & $\begin{array}{l}\text { Insertions } \\
\text { (exon 20) }\end{array}$ & $\begin{array}{l}\text { L861Q } \\
\text { (exon 21) }\end{array}$ & $\begin{array}{l}\text { L858R } \\
\text { (exon 21) }\end{array}$ & \\
\hline 1 & $\mathrm{~F}$ & 69 & North & - & + & - & - & - & - & 1 \\
\hline 2 & $\mathrm{~F}$ & 39 & North & - & + & - & - & - & - & 1 \\
\hline 3 & $\mathrm{~F}$ & 45 & North & - & - & - & - & - & - & 0 \\
\hline 4 & $\mathrm{~F}$ & 72 & South & - & + & - & - & - & - & 1 \\
\hline 5 & $\mathrm{f}$ & 59 & South & - & + & - & - & - & + & 2 \\
\hline 6 & $\mathrm{~F}$ & 40 & North & - & - & - & - & - & - & 0 \\
\hline 7 & $\mathrm{~F}$ & 62 & North & - & + & - & - & - & - & 1 \\
\hline 8 & $\mathrm{~F}$ & 62 & North & - & - & - & - & - & - & 0 \\
\hline 9 & $\mathrm{~F}$ & 43 & North & - & - & - & - & - & - & 0 \\
\hline 10 & $\mathrm{~F}$ & 62 & North & - & - & - & - & - & + & 1 \\
\hline 11 & $\mathrm{~F}$ & 56 & North & - & - & - & - & - & - & 0 \\
\hline 12 & $\mathrm{~F}$ & 64 & North & - & - & - & - & - & - & 0 \\
\hline 13 & $\mathrm{~F}$ & 76 & North & - & - & - & - & - & - & 0 \\
\hline 14 & $\mathrm{~F}$ & 58 & South & - & - & - & - & - & - & 0 \\
\hline 15 & $\mathrm{~F}$ & 55 & South & - & - & - & - & - & + & 1 \\
\hline 16 & $\mathrm{~F}$ & 55 & South & - & + & - & - & - & - & 1 \\
\hline 17 & $\mathrm{~F}$ & 31 & South & - & - & - & - & - & - & 0 \\
\hline 18 & $\mathrm{~F}$ & 45 & South & - & + & - & - & - & - & 1 \\
\hline 19 & $\mathrm{~F}$ & 55 & South & - & + & - & - & - & - & 1 \\
\hline 20 & $\mathrm{~F}$ & 69 & South & - & + & - & - & - & - & 1 \\
\hline 21 & $\mathrm{~F}$ & 71 & South & - & + & - & - & - & - & 1 \\
\hline 22 & $\mathrm{~F}$ & 51 & South & - & - & - & - & - & + & 1 \\
\hline 23 & $\mathrm{~F}$ & 50 & South & - & - & - & - & - & + & 1 \\
\hline 24 & $\mathrm{~F}$ & 64 & South & - & + & - & - & - & - & 1 \\
\hline 25 & $\mathrm{~F}$ & 45 & South & - & - & - & - & - & - & 0 \\
\hline 26 & $\mathrm{~F}$ & 70 & South & - & - & - & - & - & + & 1 \\
\hline 27 & $\mathrm{~F}$ & 37 & North & - & - & - & - & - & - & 0 \\
\hline 28 & $\mathrm{~F}$ & 60 & North & - & + & - & - & - & - & 1 \\
\hline 29 & $\mathrm{M}$ & 80 & North & - & - & - & - & - & - & 0 \\
\hline 30 & $\mathrm{M}$ & 58 & North & - & - & - & - & - & + & 1 \\
\hline 31 & $\mathrm{M}$ & 60 & North & - & - & - & - & - & - & 0 \\
\hline 32 & $\mathrm{M}$ & 50 & North & - & - & - & - & - & - & 0 \\
\hline 33 & $\mathrm{M}$ & 75 & North & - & - & - & + & - & - & 1 \\
\hline 34 & $\mathrm{M}$ & 85 & North & - & - & - & - & - & - & 0 \\
\hline 35 & $\mathrm{M}$ & 65 & South & + & - & - & - & - & - & 1 \\
\hline 36 & $\mathrm{M}$ & 92 & South & - & - & - & - & - & - & 0 \\
\hline 37 & $\mathrm{M}$ & 70 & South & - & - & - & - & - & + & 1 \\
\hline 38 & $\mathrm{M}$ & 78 & South & + & - & - & - & - & - & 1 \\
\hline 39 & $\mathrm{M}$ & 60 & South & - & + & - & - & - & - & 1 \\
\hline 40 & $\mathrm{M}$ & 76 & South & - & - & - & - & - & - & 0 \\
\hline 41 & $\mathrm{M}$ & 32 & South & - & + & - & - & - & + & 2 \\
\hline 42 & $\mathrm{M}$ & 65 & South & - & + & - & - & - & - & 1 \\
\hline 43 & $\mathrm{M}$ & 42 & South & - & + & - & - & - & - & 1 \\
\hline
\end{tabular}


continuation of Table 3.

\begin{tabular}{|c|c|c|c|c|c|c|c|c|c|c|}
\hline \multirow[t]{2}{*}{ Subject Code } & \multirow{2}{*}{$\begin{array}{l}\text { Gender } \\
\text { (F-Female, } \\
\text { M-Male) }\end{array}$} & \multirow{2}{*}{$\begin{array}{l}\text { Age } \\
\text { (in years) }\end{array}$} & \multirow{2}{*}{$\begin{array}{l}\text { South or } \\
\text { North Indian }\end{array}$} & \multicolumn{6}{|c|}{ EGFR Mutation type } & \multirow[t]{2}{*}{ \# of mutations } \\
\hline & & & & $\begin{array}{l}\text { G719X } \\
\text { (exon 18) } \\
\end{array}$ & $\begin{array}{l}\text { Deletions } \\
\text { (exon 19) }\end{array}$ & $\begin{array}{l}\text { S768I } \\
\text { (exon 20) }\end{array}$ & $\begin{array}{l}\text { Insertions } \\
\text { (exon 20) }\end{array}$ & $\begin{array}{l}\text { L861Q } \\
\text { (exon 21) }\end{array}$ & $\begin{array}{l}\text { L858R } \\
\text { (exon 21) }\end{array}$ & \\
\hline 44 & M & 16 & South & - & - & - & - & - & - & 0 \\
\hline 45 & M & 56 & South & - & - & - & - & - & - & 0 \\
\hline 46 & M & 58 & South & - & - & - & - & - & - & 0 \\
\hline 47 & $\mathrm{M}$ & 59 & South & - & - & - & - & - & - & 0 \\
\hline 48 & M & 50 & North & - & + & - & - & - & - & 1 \\
\hline 49 & M & 72 & North & - & - & - & - & - & + & 1 \\
\hline 50 & M & 90 & North & - & - & - & - & - & - & 0 \\
\hline
\end{tabular}

significant in our study. They didn't report the regional difference in the mutation rates as seen in our study. However, a recent epidemiological study of EGFR mutations in Asian patients [44] showed much lower EGFR mutation positive rate among Indian subgroup patients than what has been seen in our study \& Sahoo et al., It will be interesting to see the ethnic background of the Indian patients included in the PIONEER study as well as the smoking status of these patients. If the predominant Indian patient population in their study group include North Indians \& smokers then this may justify for the lower mutation rate (22\%) observed in their study. This falls within the confidence interval for the North Indians mutation positive rate in our study (Table 3 ).

We also observed similar mutation rates with respect to the type of mutations as seen in the East Asian [30] and Indian [26] study. In our study the deletions in exon 19 were most common (61\%) followed by L858R mutation (36\%) followed by other mutations (10.6\%). In the Mok et al., [30], the percentages were $54 \%, 43 \% \& 8 \%$ respectively. The explanation for having high mutation rate in exon 19 could be due to the local haplotype structure favouring the occurrence of EGFR mutations especially deletions in exon 19 as was shown in a study from Taiwan [41]. We had two samples (4\%) with double mutations (L858R \& Deletions). It is interesting to have samples with multiple activating mutations \& it has also been observed previously in Chinese $[\mathbf{3 1}, \mathbf{4 2}]$ \& other populations $[43,45]$.

Our study indicates a higher EGFR mutation positive rate in the lung adenocarcinoma patients compared to that of populations of European descent. It is also comparable to the findings from the studies in other Asian populations. There is also a disparity in the mutation rate between north \& south India especially in women. It is therefore important to evaluate the EGFR mutation status before prescribing the tyrosine kinase inhibitors in the case of non-smoker lung adenocarcinoma patients from North \& South India to have effective treatment outcome.

\section{Competing interests}

The authors declare that they have no competing interests.
Authors' contributions

\begin{tabular}{|l|c|c|c|c|c|}
\hline Authors' contributions & MP & MS & NS & PS & AS \\
\hline Research concept and design & $\checkmark$ & -- & -- & $\checkmark$ & $\checkmark$ \\
\hline Collection and/or assembly of data & $\checkmark$ & $\checkmark$ & $\checkmark$ & $\checkmark$ & -- \\
\hline Data analysis and interpretation & $\checkmark$ & $\checkmark$ & $\checkmark$ & $\checkmark$ & -- \\
\hline Writing the article & $\checkmark$ & $\checkmark$ & -- & -- & $\checkmark$ \\
\hline Critical revision of the article & $\checkmark$ & -- & $\checkmark$ & $\checkmark$ & $\checkmark$ \\
\hline Final approval of article & $\checkmark$ & -- & -- & $\checkmark$ & $\checkmark$ \\
\hline Statistical analysis & $\checkmark$ & -- & -- & -- & $\checkmark$ \\
\hline
\end{tabular}

Acknowledgement

We thank Dr Reddy's Laboratories for their support.

Publication history

EIC: G. J. Peters, VU University Medical Center, Netherlands.

Received: 30-Mar-2014 Final Revised: 02-May-2014

Accepted: 15-May-2014 Published: 03-Jun-2014

\section{References}

1. Ward E, Jemal A, Cokkinides V, Singh GK, Cardinez C, Ghafoor A and Thun $M$. Cancer disparities by race/ethnicity and socioeconomic status. $C A$ Cancer J Clin. 2004; 54:78-93. | Article | PubMed

2. Dikshit R, Gupta PC, Ramasundarahettige C, Gajalakshmi V, Aleksandrowicz L, Badwe R, Kumar R, Roy S, Suraweera W, Bray F, Mallath $M$, Singh PK, Sinha DN, Shet AS, Gelband $H$ and Jha P. Cancer mortality in India: a nationally representative survey. Lancet. 2012; 379:1807-16. | Article I PubMed

3. Breathnach OS, Freidlin B, Conley B, Green MR, Johnson DH, Gandara DR, O'Connell M, Shepherd FA and Johnson BE. Twenty-two years of phase III trials for patients with advanced non-small-cell lung cancer: sobering results. J Clin Oncol. 2001; 19:1734-42. | Article | PubMed

4. Herbst RS. Review of epidermal growth factor receptor biology. Int J Radiat Oncol Biol Phys. 2004; 59:21-6. I Article I PubMed

5. Zhang H, Berezov A, Wang Q, Zhang G, Drebin J, Murali R and Greene $\mathrm{MI}$. ErbB receptors: from oncogenes to targeted cancer therapies. J Clin Invest. 2007; 117:2051-8. | Article | PubMed Abstract | PubMed Full Text

6. Levitzki A. EGF receptor as a therapeutic target. Lung Cancer. 2003; 41 Suppl 1:S9-14. | Article | PubMed

7. Hirsch FR, Scagliotti GV, Langer CJ, Varella-Garcia M and Franklin WA. Epidermal growth factor family of receptors in preneoplasia and lung cancer: perspectives for targeted therapies. Lung Cancer. 2003; 41 Suppl 1:S29-42. | Article | PubMed

8. Brabender J, Danenberg KD, Metzger R, Schneider PM, Park J, Salonga D, Holscher $\mathrm{AH}$ and Danenberg PV. Epidermal growth factor receptor and HER2-neu mRNA expression in non-small cell lung cancer Is correlated with survival. Clin Cancer Res. 2001; 7:1850-5. | Article | PubMed 
9. Rusch V, Klimstra D, Venkatraman E, Pisters PW, Langenfeld J and Dmitrovsky E. Overexpression of the epidermal growth factor receptor and its ligand transforming growth factor alpha is frequent in resectable non-small cell lung cancer but does not predict tumor progression. Clin Cancer Res. 1997; 3:515-22. | Article | PubMed

10. Arteaga CL. ErbB-targeted therapeutic approaches in human cancer. Exp Cell Res. 2003; 284:122-30. | Article | PubMed

11. Rusch V, Baselga J, Cordon-Cardo C, Orazem J, Zaman M, Hoda S, Mclntosh J, Kurie J and Dmitrovsky E. Differential expression of the epidermal growth factor receptor and its ligands in primary non-small cell lung cancers and adjacent benign lung. Cancer Res. 1993; 53:237985. | Article | PubMed

12. Vikis $H$, Sato $M$, James $M$, Wang $D$, Wang $Y$, Wang $M$, Jia $D$, Liu $Y$, BaileyWilson JE, Amos $\mathrm{Cl}$, Pinney SM, Petersen GM, de Andrade M, Yang $\mathrm{P}$, Wiest JS, Fain PR, Schwartz AG, Gazdar A, Gaba C, Rothschild H, Mandal D, Kupert E, Seminara D, Viswanathan A, Govindan R, Minna J, Anderson MW and You M. EGFR-T790M is a rare lung cancer susceptibility allele with enhanced kinase activity. Cancer Res. 2007; 67:4665-70. | Article | PubMed Abstract | PubMed Full Text

13. Vokes EE and Chu E. Anti-EGFR therapies: clinical experience in colorectal, lung, and head and neck cancers. Oncology (Williston Park). 2006; 20:15-25. | Article | PubMed

14. Raymond $E$, Faivre $S$ and Armand JP. Epidermal growth factor receptor tyrosine kinase as a target for anticancer therapy. Drugs. 2000; 60 Suppl 1:15-23; discussion 41-2. | Article | PubMed

15. Wakeling AE, Guy SP, Woodburn JR, Ashton SE, Curry BJ, Barker AJ and Gibson KH. ZD1839 (Iressa): an orally active inhibitor of epidermal growth factor signaling with potential for cancer therapy. Cancer Res. 2002; 62:5749-54. | Article | PubMed

16. Lynch TJ, Bell DW, Sordella R, Gurubhagavatula S, Okimoto RA, Brannigan BW, Harris PL, Haserlat SM, Supko JG, Haluska FG, Louis DN, Christiani DC, Settleman J and Haber DA. Activating mutations in the epidermal growth factor receptor underlying responsiveness of non-small-cell lung cancer to gefitinib. N Eng/ J Med. 2004; 350:2129-39. | Article | PubMed

17. Minna JD, Gazdar AF, Sprang SR and Herz J. Cancer. A bull's eye for targeted lung cancer therapy. Science. 2004; 304:1458-61. | Article | PubMed

18. Gazdar AF, Shigematsu H, Herz J and Minna JD. Mutations and addiction to EGFR: the Achilles 'heal' of lung cancers? Trends Mol Med. 2004; 10:481-6. | Article | PubMed

19. Shigematsu $H$, Lin L, Takahashi T, Nomura M, Suzuki M, Wistuba, II, Fong KM, Lee H, Toyooka S, Shimizu N, Fujisawa T, Feng Z, Roth JA, Herz J, Minna JD and Gazdar AF. Clinical and biological features associated with epidermal growth factor receptor gene mutations in lung cancers. J Nat/ Cancer Inst. 2005; 97:339-46. | Article | PubMed

20. Paez JG, Janne PA, Lee JC, Tracy S, Greulich H, Gabriel S, Herman P, Kaye FJ, Lindeman N, Boggon TJ, Naoki K, Sasaki H, Fujii Y, Eck MJ, Sellers WR, Johnson BE and Meyerson M. EGFR mutations in lung cancer: correlation with clinical response to gefitinib therapy. Science. 2004; 304:1497-500. | Article | PubMed

21. Kim TY, Han SW and Bang YJ. Chasing targets for EGFR tyrosine kinase inhibitors in non-small-cell lung cancer: Asian perspectives. Expert Rev Mol Diagn. 2007; 7:821-36. | Article | PubMed

22. Ma BB, Hui EP and Mok TS. Population-based differences in treatment outcome following anticancer drug therapies. Lancet Oncol. 2010; 11:75-84. | Article | PubMed

23. Broet $P$, Dalmasso $C$, Tan $E H$, Alifano $M$, Zhang $S$, Wu J, Lee $M H$, Regnard JF, Lim D, Koong HN, Agasthian T, Miller LD, Lim E, Camilleri-Broet $S$ and Tan P. Genomic profiles specific to patient ethnicity in lung adenocarcinoma. Clin Cancer Res. 2011; 17:3542-50. | Article I PubMed

24. Dogan S, Shen R, Ang DC, Johnson ML, D'Angelo SP, Paik PK, Brzostowski EB, Riely GJ, Kris MG, Zakowski MF and Ladanyi M. Molecular epidemiology of EGFR and KRAS mutations in 3,026 lung adenocarcinomas: higher susceptibility of women to smoking-related KRAS-mutant cancers. Clin Cancer Res. 2012; 18:6169-77. | Article | PubMed Abstract I PubMed Full Text

25. Paik PK, Johnson ML, D’Angelo SP, Sima CS, Ang D, Dogan S, Miller VA,
Ladanyi M, Kris MG and Riely GJ. Driver mutations determine survival in smokers and never-smokers with stage IIIB/IV lung adenocarcinomas. Cancer. 2012; 118:5840-7. | Article | PubMed Abstract | PubMed Full Text

26. Sahoo R, Harini VV, Babu VC, Patil Okaly GV, Rao S, Nargund A, Venkataswamy E, Rao R and Kumar BS. Screening for EGFR mutations in lung cancer, a report from India. Lung Cancer. 2011; 73:316-9. | Article | PubMed

27. Parikh $P$, Chang AY, Nag $S$, Digumarti R, Bhattacharyya GS, Doval DC, Babu G, Chacko RT, Advani S, Ranade A, Aggarwal S, Jagannathan R, Hargreaves $L$ and Thatcher $N$. Clinical experience with gefitinib in Indian patients. J Thorac Oncol. 2008; 3:380-5. | Article | PubMed

28. Tanweer Shahid, Soma Mukhopadhyay and Jayasri Basak et al. Outcome of non-small cell lung cancer in females with gefitinib therapy: An experience from eastern India. J Clin Oncol. 2012; 30. I Article

29. M. G. Kris, B. E. Johnson and D. J. Kwiatkowski et al. Identification of driver mutations in tumor specimens from 1,000 patients with lung adenocarcinoma: The NCl's Lung Cancer Mutation Consortium (LCMC). J Clin Oncol. 2011; 29. I Article

30. Mok TS, Wu YL, Thongprasert S, Yang CH, Chu DT, Saijo N, Sunpaweravong P, Han B, Margono B, Ichinose Y, Nishiwaki Y, Ohe Y, Yang JJ, Chewaskulyong B, Jiang H, Duffield EL, Watkins CL, Armour $\mathrm{AA}$ and Fukuoka M. Gefitinib or carboplatin-paclitaxel in pulmonary adenocarcinoma. N Engl J Med. 2009; 361:947-57. | Article I PubMed

31. Huang SF, Liu HP, Li LH, Ku YC, Fu YN, Tsai HY, Chen YT, Lin YF, Chang WC, Kuo HP, Wu YC, Chen YR and Tsai SF. High frequency of epidermal growth factor receptor mutations with complex patterns in non-small cell lung cancers related to gefitinib responsiveness in Taiwan. Clin Cancer Res. 2004; 10:8195-203. | Article | PubMed

32. Qin L, Zhong W, Zhang L, Li LY and Wang MZ. Comparison of three methods for detecting epidermal growth factor receptor mutations in plasma DNA samples of Chinese patients with advanced non-small cell lung cancer. Chin Med J (Engl). 2011; 124:887-91. | Article I PubMed

33. Zhang J, Liang ZY, Zeng X, Wu SF, Gao J and Liu TH. [Detection of epidermal growth factor receptor gene mutations in non-small cell lung cancers by real-time polymerase chain reaction using scorpion amplification refractory mutation system]. Zhonghua Bing Li Xue Za Zhi. 2008; 37:294-9. | Article | PubMed

34. Kimura $H$, Suminoe $M$, Kasahara $K$, Sone $T$, Araya $T$, Tamori S, Koizumi $F$, Nishio K, Miyamoto K, Fujimura M and Nakao S. Evaluation of epidermal growth factor receptor mutation status in serum DNA as a predictor of response to gefitinib (IRESSA). Br J Cancer. 2007; 97:778-84. | Article | PubMed Abstract | PubMed Full Text

35. Zhu CQ, da Cunha Santos G, Ding K, Sakurada A, Cutz JC, Liu N, Zhang T, Marrano P, Whitehead M, Squire JA, Kamel-Reid S, Seymour L, Shepherd FA and Tsao MS. Role of KRAS and EGFR as biomarkers of response to erlotinib in National Cancer Institute of Canada Clinical Trials Group Study BR.21. J Clin Oncol. 2008; 26:4268-75. | Article | PubMed

36. Maheswaran S, Sequist LV, Nagrath S, Ulkus L, Brannigan B, Collura CV, Inserra E, Diederichs S, lafrate AJ, Bell DW, Digumarthy S, Muzikansky A, Irimia D, Settleman J, Tompkins RG, Lynch TJ, Toner M and Haber DA. Detection of mutations in EGFR in circulating lung-cancer cells. $N$ Eng/ J Med. 2008; 359:366-77. | Article | PubMed Abstract | PubMed Full Text

37. Rosenberg NA, Mahajan S, Gonzalez-Quevedo C, Blum MG, Nino-Rosales L, Ninis V, Das P, Hegde M, Molinari L, Zapata G, Weber JL, Belmont JW and Patel PI. Low levels of genetic divergence across geographically and linguistically diverse populations from India. PLoS Genet. 2006; 2:e215. | Article | PubMed Abstract | PubMed Full Text

38. Kashyap VK, Guha S, Sitalaximi T, Bindu GH, Hasnain SE and Trivedi R. Genetic structure of Indian populations based on fifteen autosomal microsatellite loci. BMC Genet. 2006; 7:28. | Article | PubMed Abstract | PubMed Full Text

39. Liu W, He L, Ramirez J, Krishnaswamy S, Kanteti R, Wang YC, Salgia R and Ratain MJ. Functional EGFR germline polymorphisms may confer risk for EGFR somatic mutations in non-small cell lung cancer, with a predominant effect on exon 19 microdeletions. Cancer Res. 2011; 71:2423-7. | Article | PubMed Abstract | PubMed Full Text 
40. Chen KY, Hsiao CF, Chang GC, Tsai YH, Su WC, Chen YM, Huang MS, Hsiung $\mathrm{CA}$, Chen $\mathrm{CJ}$ and Yang PC. EGFR polymorphisms, hormone replacement therapy and lung adenocarcinoma risk: analysis from a genome-wide association study in never-smoking women. Carcinogenesis. 2013; 34:612-9. | Article | PubMed

41. Liu W, He L, Ramirez J, Krishnaswamy S, Kanteti R, Wang YC, Salgia R and Ratain MJ. Functional EGFR germline polymorphisms may confer risk for EGFR somatic mutations in non-small cell lung cancer, with a predominant effect on exon 19 microdeletions. Cancer Res. 2011; 71:2423-7. | Article | PubMed Abstract | PubMed Full Text

42. Zhang GC, Lin JY, Wang Z, Zhou Q, Xu CR, Zhu JQ, Wang K, Yang XN, Chen G, Yang JJ, Huang YJ, Liao RQ and Wu YL. Epidermal growth factor receptor double activating mutations involving both exons 19 and 21 exist in Chinese non-small cell lung cancer patients. Clin Oncol ( $R$ Coll Radiol). 2007; 19:499-506. | Article | PubMed

43. Fiala O, Pesek M, Finek J, Bruha F, Bortlicek Z, Krejci J, Benesova L and Minarik M. [EGFR mutations in patients with advanced NSCLC]. Klin Onkol. 2012; 25:267-73. I PubMed

44. Shi Y, Au JS, Thongprasert S, Srinivasan S, Tsai CM, Khoa MT, Heeroma K, Itoh $Y$, Cornelio $\mathrm{G}$ and Yang PC. A prospective, molecular epidemiology study of EGFR mutations in Asian patients with advanced non-small-cell lung cancer of adenocarcinoma histology (PIONEER). J Thorac Oncol. 2014; 9:154-62. | Article | PubMed

45. Benesova L, Minarik M, Jancarikova D, Belsanova B and Pesek M. Multiplicity of EGFR and KRAS mutations in non-small cell lung cancer (NSCLC) patients treated with tyrosine kinase inhibitors. Anticancer Res. 2010; 30:1667-71. | Article | PubMed

\section{Citation:}

Pungliya M, Sachin M, Soumittra N, Shekar P and Shyam A. A study of incidence of EGFR mutations in non-smoker adenocarcinoma of the lung: disparity between north and south indian patients. J Cancer Ther Res. 2014; 3:4.

http://dx.doi.org/10.7243/2049-7962-3-4 